УДК 349.22

DOI https://doi.org/10.32849/2663-5313/2020.1.23

Людмила Могілевська, викладач кафедри правоохоронної діяльності та поліиіӥстики факультету № 6

Харківського національного університету внутрішніх справ

\title{
ФОРМИ ДІЯЛЬНОСТІ НАЦІОНАЛЬНОЇ ПОЛІЦЇ У СФЕРІ ЗАБЕЗПЕЧЕННЯ ПРАВ І СВОБОД ДИТИНИ
}

У статті на основі аналізу наукових поглядів вчених та норм чинного законодавства України визначено та охарактеризовано форми діяльності Начіональної полічї у сфері забезпечення прав свобод дитини. Обгрунтовано, що форми являють собою систему однорідних дій, що мають зовнішне вираження та спрямовані на реалізачію завдань і державно-владних повноважень Національної полічї України щодо створення оптимальних умов для забезпечення та вільної реалізації прав $і$ свобод людини загалом та прав і свобод дитини зокрема. Визначено, що організачійна форма необхідна для створення умов, з метою забезпечення виконання правозастосовних актів, що регламентують діяльність поліції у сфері забезпечення особистих прав і свобод людини та громадянина. Правозастосовна форма діяльності Наџіональної поліиї України полягає у створенні необхідних умов для забезпечення прав і свобод шляхом видання правозастосовних актів, що є складником системи юридичних фактів, що становить організаџійно-правовий механізм забезпечення конституиійних прав $і$ свобод. З’ясовано, що виховна форма діяльності Національної поліції України допомагає створити всі необхідні умови для підвищення рівня правосвідомості як кожного окремого громадянина, так і працівників Нацполіції в контексті захисту прав та свобод дитини. Правоохоронна форма діяльності Національної полічї̈ Украӥни спрямована на охорону найважливіших суспільних відносин, врегульованих нормами права, від будь-яких посягань та безпосередньо пов'язана із забезпеченням прав $i$ свобод громадян, а також створенням найбільш сприятливих умов для їх реалізаиї. Зроблено висновок, що форма діяльності національної полічії у сфері забезпечення прав і свобод дитини дає нам уявлення про шляхи та напрями впливу Нацполіиї на правовідносини у сфері забезпечення прав та свобод дитини. Також усі представлені у науковому дослідженні форми становлять собою систему, тобто иілісну, внутрішньо узгоджену сукупність, а тому мають застосовуватися комплексно, на мічній науковій основі, з урахуванням спещифіки правового статусу неповнолітніх та зовнішніх факторів.

Ключові слова: форма, правова форма, Національна поліція, права та свободи, дитина, неправова форма.

Постановка проблеми. Робота правоохоронних органів, як і будь-яка інша державно-владна діяльність, має своє зовнішнє вираження, що проявляється у відповідних формах. Останні ж повинні відповідати реальним потребам охорони і захисту прав і свобод людини та громадянина загалом, а також прав та свобод дитини зокрема. А зважаючи на те, що наше дослідження відбувається під час реформування поліції, яке, окрім всього іншого, проходить в умовах активізації злочинності й зростання кількості правопорушень, то, як справедливо зазначає I. В. Гамалій, для забезпечення достатнього рівня ефективності діяльності поліції необхідно критично переглянути й визначити адекватні й результативні форми забезпечення прав та свобод людини і громадянина [1, с. 2; 2]. А отже, дослідження форм діяльності Національної поліції у сфері забезпечення прав і свобод дитини має важливе теоретичне та практичне значення.
Стан дослідження. Варто відзначити, що багато проблем щодо діяльності Національної поліції України у сфері захисту прав та свобод людини вже були у полі зору науковців, зокрема їм приділяли увагу: О. М. Бандурка, О. І. Безпалова, Л. Д. Березівська, О. І. Вінгловська, В. В. Галунько, О. Ю. Дрозд, П. І. Каблак, I. В. Міщук, О. М. Музичук, В. М. Олійник, В. Г. Петров, А. О. Попова, А. В. Рум'янцеваКозовник, М. І. Смирнов, Н. Б. Шамрук, С. І. Шевченко, К. В. Шкарупа, О. Ю. Шостко та багато інших. Однак, незважаючи на чималу кількість наукових розробок, у більшості праць проблема визначення форм діяльності Національної поліції України у сфері захисту прав та свобод людини або не розглядалась взагалі, або ж мала суто поверхневий характер.

Метою статті $є$ визначення та надання характеристики форм діяльності Національної поліції у сфері забезпечення прав і свобод дитини. 
Виклад основного матеріалу. Розкриваючи зміст категорії «форма», звернемось до її словникового значення. Так, у Великому тлумачному словнику сучасної української мови вона визначається, як: 1) обриси, контури, зовнішні межі предмета, що визначають його зовнішній вигляд; 2) пристрій, шаблон, за допомогою якого чому-небудь надають певних обрисів, якогось вигляду; 3) спосіб існування змісту, його внутрішня структура, організація і зовнішній вираз; 4) видимість, зовнішній бік чого-небудь, що не відображає суті справи [3, с. 972]; а також спосіб здійснення, виявлення будь-якої дії; суворо встановлений порядок у будь-якій справі [4, с. 665]. Форма у філософії - це ще й порядок розташування елементів, внутрішня структура цілого, тому кожна форма окремо - «це певна частина діяльності органу, його структурних підрозділів та особового складу < ..> Вся управлінська діяльність складається з певних форм, кожна з яких об'єктивно виражена і відрізняється від інших форм» [5]. Зокрема, В. Б. Авер'янов під формами державного управління розумів відмінні за характером і наслідками способи зовнішнього вираження діяльності органів виконавчої влади [6, с. 277]. Варто наголосити, що від оптимального використання тих чи інших форм державного управління залежить ефективність діяльності поліції, а також виконання покладених на неї завдань загалом та у частині забезпечення прав і свобод дитини.

Тож, конкретизуючи поняття форм через призму діяльності поліції, зазначимо такі позиції. На думку В. М. Макарчука, під формою адміністративно-правової діяльності правоохоронних органів слід розуміти зовнішню характеристику адміністративної діяльності, яка виявляється у здійсненні індивідуальних організаційноправових дій, що спрямовані на запобігання та припинення правопорушень, проступків, організації та забезпечення громадського порядку [7, с. 183]. К. Б. Толкачев та А. Г. Хабібулін під формами діяльності органів внутрішніх справ у сфері забезпечення особистих конституційних прав і свобод людини розуміють сукупність однорідних, конкретних дій їх працівників: 1) що пов'язані зі створенням оптимальних умов для того, щоб громадяни вільно користувались благами особистої свободи; 2) які пов'язані з усуненням негативних факторів, що ускладнюють реалізацію особистих прав і свобод; 3) які пов'язані із забезпеченням можливостей для здійснення умов щодо забезпечення особистих прав і свобод людини та громадянина, що відбувають покарання за вчинення правопорушень [8, с. 116]
І. П. Голосніченко та Я. Ю. Кондратьєв розуміють форми діяльності органів внутрішніх справ як однорідні за своїм характером та правовою природою групи адміністративних дій, що мають зовнішній вираз, за допомогою яких забезпечуються охорона прав громадян, громадський порядок, громадська безпека та здійснюється боротьба 3 правопорушеннями [9, с. 104]. О. Бандурка, досліджуючи правові форми діяльності органів внутрішніх справ у сфері забезпечення громадської безпеки, трактує їх як зовнішні прояви державно-владної діяльності, за допомогою яких організовується і реалізується виконання завдань органів внутрішніх справ [10, с. 78]. Необхідно погодитися 3 думкою А. В. Румянцевої-Козовник з приводу того, що формам діяльності органів внутрішніх справ притаманна універсальність, оскільки діяльність цих органів щодо реалізації їхніх завдань і функцій здійснюється в рамках тих форм, які визначено для них законом [11, с. 116-117].

Таким чином, на основі викладеного вище під формами діяльності поліції у сфері забезпечення прав та свобод дитини пропонуємо розуміти систему однорідних дій, що мають зовнішнє вираження і спрямовані на реалізацію завдань та державно-владних повноважень Національної поліції України щодо створення оптимальних умов для забезпечення та вільної реалізації прав і свобод людини загалом та прав і свобод дитини зокрема.

Численні та різнопланові завдання поліції зумовлюють різноманіття форм її діяльності. Проте Нацполіція, яка наділена державно-владними повноваженнями, у своїй діяльності повинна використовувати тільки форми, передбачені відповідними правовими актами. Вони закріплені в законодавстві, яке визначає правовий статус поліції: законах, положеннях, статутах, наказах, інструкціях та інших актах. Водночас особливий характер завдань поліції та специфіка оперативної обстановки передбачає певну самостійність у виборі тих чи інших встановлених законодавством форм, вибір яких проводиться з урахуванням конкретних життєвих обставин, вимог ефективності і доцільності.

Найбільш поширеним у науці є поділ форм діяльності поліції на правові (юридичні) та неправові. Критерієм для такої класифікації $€$ наявність чи відсутність юридичних наслідків реалізації відповідної форми. Правові форми - це діяльність, яка пов'язана з виконанням юридично значущих дій у чітко встановленому законом порядку. Вони визначаються природою суб'єкта державної влади та його компетенцією у сфері 
здійснення державно-владних повноважень [12, с. 110]. До них здебільшого відносять такі: а) видання управлінських актів; б) вчинення інших юридично значущих управлінських дій; в) укладання адміністративно-правових договорів. Натомість до неправових відносять такі форми: а) здійснення організаційних заходів; б) матеріально-технічні операції. Останні мають допоміжне, обслуговуюче призначення [13, с. 64$]$.

На думку вченого А. П. Корнєва, адміністративно-правова діяльність правоохоронних органів здійснюється у формах матеріально-технічних операцій, організаційних заходів, нормотворчої, правозастосовної (регулятивної та правоохоронної) діяльності. Крім того, автор переконаний, що форми адміністративно-правової діяльності правоохоронних органів можуть бути зовнішні та внутрішні. Зовнішня форма адміністративно-правової діяльності правоохоронних органів виявляється в практичній реалізації повноважень і функцій правоохоронного органу, наприклад у роботі з громадянами. Внутрішня форма передбачає організацію робочого процесу в правоохоронному органі [14, с. 149-150].

Цікавою є точка зору Л. Ю. Іванової, яка розглядає та поділяє форми адміністративної діяльності правоохоронних органів за способом, цілеспрямованістю та змістом. За змістом дослідниця виокремлює дві правові форми, а саме правозастосовну та нормотворчу. Правозастосовна передбачає діяння суб'єктів із застосування норм права, а нормотворча застосовується ними лише в межах їхніх повноважень. За способом виокремлюються правозастосовні форми адміністративної діяльності: внутрішні та зовнішні, правоохоронні та регулятивні, які своєю чергою можуть бути усними (розпорядження, вказівки, накази), конклюдентними (певні регулюючі жести), письмовими (індивідуальний акт). За цілеспрямованістю (мається на увазі мета використання) правові форми адміністративної діяльності поділяються на внутрішні, тобто такі, що пов'язані $з$ внутрішньою діяльністю в правоохоронному органі (діловодство, матеріальне забезпечення тощо), і зовнішні, які використовуються для реалізації суб'єктами адміністративної діяльності покладених завдань і функцій. Неправові форми поділяються на форми, що виявляються в організаційних діях (нарада, інструктаж тощо), і форми, що виявляються в матеріально-технічних діях (виконання матеріалів, видання довідок, складання звітів тощо) [15, с. 57-60].

Незважаючи на вказане вище, слід все ж таки зазначити, що форми адміністративно- правової діяльності правоохоронних органів вченими найбільш часто поділяються саме на правові та неправові. Однак у ході здійснення адміністративної діяльності правоохоронним органом можуть здійснюватися також інші форми адміністративної діяльності, але, по суті, вони випливають із правових або неправових та тісно пов'язані між собою [16, с. 445].

Тож для встановлення правових форм діяльності Нацполіції у сфері захисту прав та свобод дитини пропонуємо звернутись до виділення форми їхної діяльності у поєднанні зі сферою забезпечення прав і свобод людини та громадянина, перелік яких деякі автори також визначають по-різному. Так, одні вчені включають до правових форм нормотворчу, правозастосовчу й правоохоронну діяльність. Серед них найголовнішою визначають саме правоохоронну $[17$, с. 20]. Інші ж не поділяють форми на правові та організаційні, позицію яких підтримуємо й ми, відносять до видів форм діяльності поліції у сфері забезпечення прав і свобод: правозастосовну; організаційну; виховну; правоохоронну.

Таким чином, ми бачимо наявний тісний зв'язок і взаємодію між неправовими (організаційними) та правовими формами у діяльності поліції щодо захисту прав та свобод дітей. У зв'язку з цим пропонуємо виділити такі форми діяльності Національної поліції України у сфері захисту прав та свобод дитини:

1) Організаційна форма, яка перш за все необхідна для створення умов з метою забезпечення виконання правозастосовних актів, що регламентують діяльність поліції у сфері забезпечення особистих прав і свобод людини та громадянина. Усе це робиться для налагодження взаємозв'язку між найрізноманітнішими органами держави, що допомагає цим органам обмінюватись позитивним досвідом, розробляти найефективніші заходи щодо реалізації прав і свобод людини та громадянина, дозволяє контролювати посадових осіб на предмет виконання ними норм права, що гарантують права та свободи людини та громадянина, дозволяє впливати на поведінку самих громадян у процесі реалізації ними своїх прав і свобод, а в разі порушень застосовувати ефективні засоби впливу i, нарешті, усувати недоліки чи прогалини в цій сфері [18, с. 420-421]. Виявляється вказана форма у кількох аспектах. По-перше, це робота, що проводиться безпосередньо в органах внутрішніх справ (так би мовити внутрішньо-апаратна робота) - наради, службова підготовка, перепідготовка та підвищення кваліфікації працівників органів внутрішніх справ, інспекторські перевірки, індивіду- 
ально-виховна робота тощо; по-друге, робота з громадськістю - повідомлення, виступи перед населенням, тематичні лекції, виступи у ЗМІ і т. ін. Ще одна форма організаційного характеру - це робота із заявами та повідомленнями осіб, аналітичними матеріалами моніторингу щодо стану забезпечення прав i свобод людини органами внутрішніх справ [17, с. 20]. Організаційна форма має на меті сприяння створенню ефективних умов за яких співробітники поліції реалізують свої повноваження в тому числі з метою захисту прав та свобод дитини. Це досягається шляхом створення умов функціонування органів Нацполіції як ззовні, так і зсередини. Зазначене, своєю чергою, забезпечується як фінансовим і технічним забезпеченням підрозділів, організацією спеціальної підготовки у разі проведення операцій та реалізації тактичних заходів, так і вирішенням проблем у створенні умов для реалізації громадянами своїх прав та свобод, а також наданням їм певної інформації, виданням відповідних рішень та адміністративно-правових актів. Наприклад, це може бути організація взаємодії підрозділів Нацполіції з іншими територіальними та лінійними підрозділами, службами у справах дітей, адміністраціями навчальних закладів щодо профілактики правопорушень серед неповнолітніх або організаційні заходи щодо розшуку неповнолітніх, що пішли з дому та не повернулись, а також видача паспорта неповнолітній особі з моменту досягнення нею 14 років, затримання та повернення додому неповнолітньої особи, яка жебракуе та займається бродяжництвом - усе це створює умови для реалізації ними своїх прав та свобод тощо [11, с. 117-118].

2) Наступна форма, якій ми приділимо увагу в контексті вибраної проблематики, - правозастосовна, як полягає у створенні необхідних умов для забезпечення прав і свобод шляхом видання правозастосовних актів, що є складником системи юридичних фактів, що становить організаційно-правовий механізм забезпечення конституційних прав і свобод. Головною метою таких актів є конкретизація змісту прав і свобод, встановлення порядку, меж і підстав їх реалізації та індивідуалізації інших юридичних фактів, 3 якими пов'язане здійснення прав і свобод [19]. Так, Національна поліція України видає відомчі нормативні акти, які дозволяють їх підрозділам виконувати функції щодо забезпечення прав та свобод неповнолітніх. Це реалізується шляхом застосування правових норм із прийняттям державно-владних рішень для реалізації прав та свобод. Отже, у системі гарантій прав і свобод людини правозастосування підпорядковане завданням охорони прав, тобто припиненню, розкриттю і розслідуванню злочинів та адміністративних проступків [20, с. 142-145].

3) Окрему увагу також слід приділити виховній формі, яка допомагає створити всі необхідні умови для підвищення рівня правосвідомості як кожного окремого громадянина, так і працівників Нацполіції в контексті захисту прав та свобод дитини. Виховна робота в поліції - це насамперед цілеспрямована діяльність керівників усіх рівнів, громадських інститутів щодо формування в особового складу високих громадянських, моральних і професійних якостей, мобілізації на успішне виконання оперативнослужбових завдань, укріплення законності та зміцнення службової дисципліни. В умовах формування правової держави виховна робота, що проводиться поліцією, набула особливої актуальності.

4) I остання форма діяльності Національної поліції України, якій ми приділимо увагу в контексті забезпечення прав та свобод дитини, - правоохоронна. Вона спрямована на охорону найважливіших суспільних відносин, врегульованих нормами права, від будь-яких посягань. Ця форма безпосередньо пов'язана із забезпеченням прав і свобод громадян, а також створенням найбільш сприятливих умов для їх реалізації [21, с. 10]. Варто відзначити, що правоохоронною вважається не вся діяльність поліції, а лише та, яка визначається діями, спрямованими на припинення протиправної поведінки.

\section{Висновки}

Таким чином, форма дає нам уявлення про шляхи та напрями впливу Нацполіції на правовідносини у сфері забезпечення прав та свобод дитини. Переконані, що всі представлені у науковому дослідженні форми становлять собою систему, тобто цілісну, внутрішньо узгоджену сукупність, а тому мають застосовуватися комплексно, на міцній науковій основі, з урахуванням специфіки правового статусу неповнолітніх та зовнішніх факторів. Слід також зауважити, що окреслений нами перелік форм діяльності Національної поліції у сфері забезпечення прав i свобод дитини в жодному разі не можна назвати вичерпним, оскільки і законодавець, і вчені повинні здійснювати постійний пошук нових, більш дієвих і якісних форм, які сприятимуть якісному покращенню стану захисту прав дітей в Україні.

\section{Список використаних джерел:}

1. Гамалій І. В. Теоретичні проблеми правового регулювання діяльності міліції щодо забез- 
печення реалізації конституційних прав і свобод громадян : автореф. дис. ... канд. юрид. наук: 12.00.01. Київ, 2000. 17 с.

2. Лящук Р. М. Методи переконання та примусу в адміністративній діяльності правоохоронних органів. Порівняльно-аналітичне право. 2016. № 3. С. $148-150$.

3. Великий тлумачний словник сучасної української мови / уклад. і голов. ред.В. Т. Бусел. Київ-Ірпінь: Перун, 2005. 1728 с.

4. Новий тлумачний словник української мови : у 3-х т. / уклад. В. В. Яременко, О. М. Сліпушко. 2-е вид. Київ: АКОНІТ, 2004. Т. 3: П-Я. 862 с.

5. Чичерін Б.Н. Філософія права. Москва, 1900. C. 301.

6. Адміністративне право України. Академічний курс : підручник : у 2-х т. / ред. колегія: В. Б. Авер'янов (голова). Київ: «Юридична думка», 2004. Т. 1 : Загальна частина. 584 с.

7. Макарчук В. Н. Методы и формы административной деятельности участковых инспекторов милиции : дис. ... канд. юрид. наук: 12.00.07. Москва, 1992. 205 с

8. Толкачев К. Б., Хабибулин А. Г. Органы внутренних дел в механизме обеспечения личных конституционных прав и свобод граждан : монография. Уфа: Уфимская высшая школа МВД РФ, 1991. 169 c

9. Адміністративна діяльність органів внутрішніх справ. Загальна частина / за ред. І.П. Голосніченко. Київ: Укр. акад. внутр. справ, 1995. 177 с

10. Бандурка О. М. Основи управління в органах внутрішніх справ. України: теорія, досвід, шляхи удосконалення. Харків: Основа, 1996. 398 с.

11. Рум'янцева-Козовник А. В. Форми та методи адміністративної діяльності ОВС з охо- рони прав дитини. Свропейські перспективи. 2014 № 3. С. 116-122.

12. Атаманчук Г. В. Государственное управление (организационно-функциональные вопросы) Москва : ОАО «НПО «Экономика», 2000. 302 с.

13. Гончарук С. Т. Основи адміністративного права України : навчальний посібник. Київ, 2004. $200 \mathrm{c}$

14. Корнев А. П. Нормы административного права и их применение. Москва : Юрид. лит., 1978. $194 \mathrm{c}$

15. Іванова Л. Ю. Класифікація форм адміністративно-юрисдикційної діяльності органів внутрішніх справ. Право і безпека. 2012. № 4. С. 57-61

16. Петров В. Г. Форми адміністративно-правової діяльності правоохоронних органів. Наукові праиі НУ ОЮА. С. 442-447.

17. Негодченко О. В. Забезпечення прав і свобод людини органами внутрішніх справ України монографія. Дніпропетровськ : Юридична академія МВС України, 2002. 416 с

18. Филипенко Є. П. Особливості методів діяльності Органів внутрішніх справ України щодо забезпечення прав і свобод неповнолітніх. Право і безпека. 2010. № 3 (35). С. 109-113.

19. Гіда Є. О. Основні форми та методи діяльності української міліції у сфері реалізації прав і свобод людини. Науковий вісник. № 1 . 2004. С. 345-353.

20. Васильев А. С. Административное право Украины (общая часть) : учебное пособие. Харків : Право, 2001.316 с.

21. Боняк В. О. Забезпечення прав людини у правоохоронній діяльності : навчальний посібник. Дніпро: Дніпроп. держ. ун-т внутр. справ; Ліра ЛТД, 2017. 224 c.

In the article, on the basis of the analysis of scientific vieres of scientists and norms of the current legislation of Ukraine, the forms of activity of the National Police in the sphere of child rights and freedoms are defined and characterized. It is substantiated that forms of a system of homogeneous actions, which have an external expression, and which are aimed at the implementation of tasks and state authorities of the National Police of Ukraine to create optimal conditions for ensuring and free exercise of human rights and freedoms in general, and the rights and freedoms of the child in particular. It is determined that the organizational form is necessary to create conditions in order to ensure the enforcement of enforcement acts regulating the activities of the police in the field of protection of personal rights and freedoms of the individual and the citizen. The enforceable form of activity of the National Police of Ukraine is to create the necessary conditions for securing rights and freedoms by issuing en forceable acts, which is an integral part of the system of legal facts, which is an organizational and legal mechanism for ensuring constitutional rights and freedoms. It is found out that the educational form of the form of activity of the National Police of Ukraine helps to create all the necessary conditions for raising the level of justice of both individual citizens and employees of the National Police in the context of protection of the rights and freedoms of the child. The law enforcement activity of the National Police of Ukraine is aimed at protecting the most important public relations governed by the rules of law from any encroachment, and directly related to the protection of the rights and freedoms of citizens, as well as to create the most favorable conditions for their implementation. It is concluded that the form of activity of the national police in the sphere of the rights and freedoms of the child gives us an idea of the ways and directions of influence of the National Police on the legal relations in the sphere of the rights and freedoms of the child. Also, all forms presented in scientific research constitute a system, that is, a coherent, internally coherent set, and must therefore be applied in a comprehensive, sound scientific manner, taking into account the specifics of the legal status of minors and external factors.

Key words: form, legal form, national police, rights and freedoms, child, non-legal form. 